\title{
Selecting and Evaluating Suppliers in the Czech Construction Sector
}

\author{
Tomáš Hanák, Iva Nekardová1 \\ ${ }^{1}$ Institute of Structural Economics and Management, Faculty of Civil Engineering, Brno University of Technology, Veveří 331/95, \\ 602 00, Brno, Czech Republic \\ * Corresponding author, e-mail: hanak.t@fce.vutbr.cz
}

Received: 19 October 2018, Accepted: 13 October 2019, Published online: 19 March 2020

\begin{abstract}
Selecting a capable contractor is one of the crucial prerequisites for the successful completion of a construction project. This paper addresses the issue of selecting and measuring the performance of suppliers. Using a web-based questionnaire survey, quantitative data was collected from Czech construction companies that act as main contractors and subcontractors within the supply chain. The data was evaluated by applying absolute and relative frequency, the relative importance index and the chi-square test of independence. The findings revealed several managerial implications for purchasing professionals in both areas. The findings were of interest with regard to the significance of individual selection criteria in the selection of suppliers. Data was analysed on both the usage of performance measurement systems and the frequency of performance measurement. We concluded that somewhat large differences exist between main contractors and subcontractors in terms of the use of selection criteria and that performance measurement is not universally applied in the Czech construction sector.
\end{abstract}

Keywords

construction, contractor, performance measurement, supply chain

\section{Introduction}

Construction projects often suffer from poor performance, and one of the possible reasons for this is the selection of underperforming contractors. It is therefore crucial to conduct proper prequalification of prospective suppliers and choose a suitable method for their evaluation and selection.

It is a well-established fact that in the construction sector many private buyer-supplier relationships are based on long-term cooperation, experience and mutual trust. Trust is considered an important element in inter-company relationships between the parties involved in a project (Ceric, 2015). However, buyers should monitor each relationship to be aware of the performance of their suppliers.

This paper aims to explore the practices that are used within selected areas of supplier quality management. In particular, the paper focuses on supplier selection and performance measurement in Czech construction sector. The international literature includes a variety of studies in this area and this paper aims to contribute a recent Czech survey to the current body of knowledge.

The paper is structured as follows: firstly, the available literature is reviewed, especially focusing on the topics of supplier selection and performance measurement. Secondly, materials and methods applied are introduced. Thirdly, results and discussion are presented. Finally, conclusions are formulated and future research direction is outlined.

\section{Literature review}

The selection of suppliers and measurement of their performance form part of the wider area of supplier quality management (Yousef AlMaian et al., 2015). The current body of knowledge includes many papers on supplier quality management in the construction industry. The literature reviewed can be categorized in two main areas. The first deals with supplier selection and the second involves supplier performance measurement.

Supplier assessment can be considered with regard to the diversity of the purchasing situation (Kraljic, (1983), or in terms of its emergency, (Samson and Voyer, 2014) or the criteria and methodology applied (Vörösmarty and Dobos, 2019). It should be noted that the range of selection criteria that are used in practice and in research studies is very broad. Taylan et al. (2018) worked with a set of 41 criteria 
distributed among 5 groups (financial, technical, managerial, health \& safety and reputation); Hasnain et al. (2018) considers 15 factors grouped into five main criteria (cost, performance, quality control, health \& safety and project control), while the model used by Zavadskas et al. (2008) refers to bid estimates, the construction duration guarantee period, experience, references, communication with stakeholders and the quality of completed projects. Furthermore, each of the three studies differs in its approach, with Taylan et al. (2018) employing a combination of AHP and TOPSIS, Hasnain et al. (2018) applying an analytical network process, and Zavadskas et al. (2008) working with the Hodges-Lehmann rule. In addition to the aforementioned approaches, the fuzzy sets theory (Krzemiński, 2015) and the use of PROMETHEE (Araújo et al., 2016) are also noteworthy.

These few examples suffice to show that a range of different approaches and practices have been used. Two aspects need to be addressed in this context. First, it should be noted that different sets of criteria tend to be employed for public and private projects. For instance, Topcu (2004) concluded that public projects in Turkey are usually awarded on the basis of the lowest bid offered by a qualified contractor. Similarly, the lowest bid price is usually the main (and often the only) criterion for selection of the contractor in Czech and Polish public procurement in the construction sector (Kozik et al., 2015). In the private sector, however, other criteria may also play an important role, such as an existing mutual relationship or the ability to respond flexibly to changes in the project. The statistically significant difference between the degree of importance assigned to individual criteria among public and private buyers has been demonstrated by Singh et al. (2006). For instance, within international construction projects, top managers in the main contracting company rarely select potential subcontractors directly and personal relationships are also considered a selection criterion (Ulubeyli et al., 2010).

The criteria for evaluating potential suppliers including their weights must be defined prior to the procurement process. Unfortunately, due to the complex nature of construction projects, many projects are plagued by uncertainty in the performance estimation, particularly in relation to performance ratings and criteria weights (Safa et al., 2014). It is not uncommon that decision-makers have to work with incomplete information or knowledge about the project as a whole (Jaskowski et al., 2010) while construction projects are often subject to changes during their implementation, including in terms of cost and time overruns (Larsen et al., 2016).
Continuous monitoring of supplier performance is an important prerequisite for being able to predict a supplier's future performance. Pesämaa et al. (2018) even argue that performance feedback has a significant positive and direct effect on the overall performance of the construction process. The performance evaluation of suppliers is usually based on criteria such as their ability to deliver on time, within the budget and to the specifications (Qian Li et al., 2017).

The concept proposed by de Araújo et al. (2017) considers 6 types of criteria (relations, management, quality, personnel, time, financial) and proposes a verbal and numerical scale of judgment. Some researchers analyse only one aspect in more detail. For instance, Dormohammadi et al. (2017) developed a model of 123 indicators for performance assessment in health, safety and environment. A non-parametric linear programming method called Data Envelopment Analysis can also be used for measuring the efficiency of decision-making units (Markovits-Somogyi et al., 2011).

Considerable attention should also be paid to quality control as quality affects not only safety in the operational life of a particular structure, but also its life cycle costs. Such an approach is widely applicable e.g. in measuring the quality of motorways, where a set of technical quality characteristics can be created and monitored (e.g. density, asphalt content, gradation etc.) (Elyamany et al., 2013). Several performance management frameworks have been proposed for the construction industry, e.g. one based on balance scorecard and EFQM by Vukomanovic and Radujkovic (2013).

This review of the available literature has shown that practical approaches as well as scholarly developments within the area of supplier selection and performance measurement are varied and, therefore, further research from other geographical areas could contribute to the current body of knowledge and potentially reveal new and unique approaches.

\section{Materials, methods and hypotheses}

The Czech Republic has been selected as the study area for analysis of practices related to the selection and performance measurement of suppliers. The fundamental characteristics of the study area are provided in Table 1.

Table 1 Basic characteristics of the study area (Czech Statistical Office)

\begin{tabular}{lll}
\hline Parameter & Value & Valid as of \\
\hline Population & $10,625,449$ & Jun 30, 2018 \\
Average gross wage & 1,251 EUR & Q2 2018 \\
Inflation rate & $2.3 \%$ & August 2018 \\
Annual GDP growth rate & $2.4 \%$ & Q2 2018 \\
$\begin{array}{l}\text { Annual volume of } \\
\text { construction works }\end{array}$ & $17,813 * 10^{6}$ EUR & 2017 \\
\hline
\end{tabular}


The aim of the survey was to collect recent data from construction companies on the areas under examination, i.e. the selection and performance measurement of suppliers. It started with a review of existing studies, which is presented in Section 2. Based on the knowledge thus gained, a questionnaire survey was developed, made up of 30 questions. The questionnaire was divided into three main sections.

The first section contained general questions aimed at obtaining data characterizing the respondents (e.g. the legal form of the business, the size of the company, the role of the company in the supply chain [main contractor or subcontractor], and the sector in which the company operates). The size of the company is measured in terms of the number of employees and is based on Commission Recommendation 2003/361/EC (2003).

The main contractor is defined as a company which signed a contract with the client, while subcontractor is a company delivering some part(s) of works to the main contractor without any direct contractual relationship with the final client.

In the second section, aspects relating to the selection of suppliers were examined (the importance of the criteria used to select suppliers, e.g. the weight of the price criterion). Respondents were asked to evaluate 7 predefined criteria (acquisition price and the related terms and conditions, price guarantees, quality of materials used, financial health of the supplier, logistics, communication and longterm cooperation with the supplier, and delivery date) and they were also allowed to add other criteria to use.

The third section of the survey focused on performance measurement of suppliers. Questions enquired about on the (non-)usage of performance measurement, methods used (Čujan and Málek, 2008), frequency of measurement and the importance of performance indicators (such as the quality of communication, meeting deadlines for delivery, the number of claims of defects, etc.).

Regarding the detection of significance criteria, a 5-point Likert scale was applied. The Likert scale is used to identify the level of agreement (Kovačić et al., 2014) or significance (Hanák and Šelih, 2017) for a series of items. The scale was designed from 1 denoting the least significant to 5 denoting the most significant criterion.

Data on the significance criteria were processed by using the Relative Importance Index (RII), which refers to the value in interval [0-1]. RII is calculated as follows (Rajgor et al., 2016):

$$
R I I=\sum W /\left(A^{*} N\right),
$$

where $\mathrm{W}$ is the weight assigned to each criterion by the respondents ranging from 1 to 5; A is the highest weight and $\mathrm{N}$ is the total number of respondents. The higher the RII value, the more significant the criterion of supplier selection / performance evaluation.

Selected relationships among categorical variables were also examined by using the chi-square test of independence at a $95 \%$ confidence level.

\subsection{Research hypotheses}

Analysis of the data allowed two relations of selected categorical variables to be statistically tested. The first hypothesis (H1) aimed to verify whether a statistically significant relation existed between two categorical variables: the role of the company in the supply chain and the type of cooperation with suppliers. The first hypothesis is as follows:

H1: The type of cooperation with suppliers is dependent on the role of the company in the supply chain.

The second hypothesis (H2) aimed to reveal potential relationship between the role of the company in the supply chain and the type of performance measurement system used. Accordingly, the second hypothesis is formulated as follows:

H2: The type of performance measurement system used is dependent on the role of the company in the supply chain.

\section{Results and discussion}

\subsection{Descriptive statistics of the sample}

In total, 668 companies were invited to participate in this survey. We received 101 valid responses, representing a $15.1 \%$ rate of response. Table 2 shows the distribution of the sample by company size.

With respect to the sector in which the company operates, the overwhelming majority of respondents focus on the construction of buildings (74.3\%), followed by traffic structures (15.8\%), and other structures (9.9\%).

A crucial question was related to the role of the company in the supply chain, i.e. whether it acted as the main contractor or a subcontractor (see Fig. 1).

As the respondents are well distributed among the categories Main Contractor (MC) and Subcontractor (SC),

Table 2 Distribution of the sample in terms of company size

\begin{tabular}{llll}
\hline $\begin{array}{l}\text { Classification of } \\
\text { the company }\end{array}$ & $\begin{array}{l}\text { Number of } \\
\text { employees }\end{array}$ & $\begin{array}{l}\text { Absolute } \\
\text { frequency }\end{array}$ & $\begin{array}{l}\text { Relative } \\
\text { frequency }\end{array}$ \\
\hline Micro & $<10$ & 22 & $21.8 \%$ \\
Small & $10-49$ & 37 & $36.6 \%$ \\
Medium & $50-249$ & 30 & $29.7 \%$ \\
Large & $>249$ & 12 & $11.9 \%$ \\
\hline
\end{tabular}




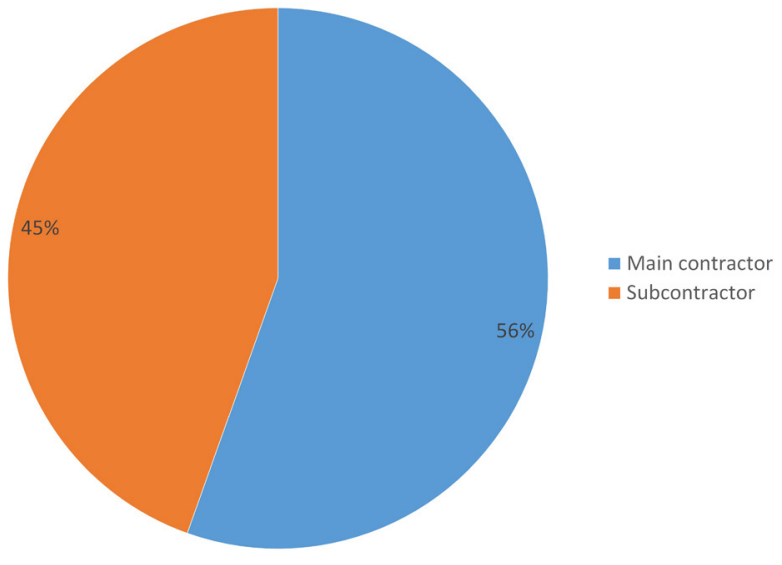

Fig. 1 Distribution of the sample in terms of role in the supply chain

the following analysis will take this categorical variable into consideration.

\subsection{Selection of suppliers}

This section examines questions relating to the selection of suppliers of construction works and materials (i.e. deliveries relating to the physical implementation of construction projects). The financial value of the delivery was not taken into account at this stage of the research. The first question concerns whether respondents only have permanent and verified suppliers or whether they also have other suppliers engaged occasionally as the need arises; or if they do not have any permanent and verified suppliers. Statistics are provided in Table 3.

Table 3 clearly shows that respondents do not prefer to cooperate exclusively with occasional suppliers. Only three companies from the entire sample replied that they did not have permanent suppliers. In order to determine whether the role in the supply chain is associated with the type of

Table 3 Types of cooperation with suppliers

\begin{tabular}{lcc}
\hline Response & MC & SC \\
\hline Just permanent & $14(25.0 \%)$ & $15(33.3 \%)$ \\
Both permanent and occasional & $41(73.2 \%)$ & $28(62.2 \%)$ \\
Just occasional & $1(1.8 \%)$ & $2(4.4 \%)$ \\
\hline
\end{tabular}

cooperation with suppliers which companies are engaged in (H1), a chi-square test of independence was applied to a reduced sample (i.e. the category "Just occasional" was removed for this purpose). The $\chi^{2}$ test of independence has a value of 1.03 under a 1 degree of freedom $\chi^{2}$ distribution, which results in a p-value of 0.310 . Therefore, there is not enough evidence to reject the null hypothesis of the independence of the examined categorical variables. Hypothesis H1 is not supported.

The next set of questions inquired about the significance of particular criteria that are used within the process of supplier selection. Respondents were asked to rank a total of 7 criteria by assigning a weight of significance to each. Table 4 shows the resulting values of RII for each criterion separately for the MC and SC categories.

The data obtained clearly show the differences in significance accorded to each criterion in relation to role of the company in the supply chain. Main contractors appear to value communication, long-term cooperation, delivery date, and price guarantees $(\mathrm{RII}=0.932 ; 0.914 ; 0.900$ respectively). This means that $\mathrm{MC}$ prefer to cooperate with verified suppliers with whom they have developed a long-term relationship. It is also very important for them that these suppliers are able to deliver on time and that they can guarantee that the agreed price will not change. Subcontractors evaluated the quality of material used as the most significant criterion. This can be attributed to the fact that subcontractors bear the ultimate responsibility for the quality of material as any claims in this respect on the part of the client will be transferred from the main contractor to the subcontractors. In general, selection criteria have a higher significance for main contractors. One possible explanation for the slightly lower overall significance of selection criteria for subcontractors is that they usually only buy material while the rest of the contract with the $\mathrm{MC}$ consists of tasks performed by their own workers.

Table 4 Significance of selection criteria (RII)

\begin{tabular}{|c|c|c|c|c|c|}
\hline \multicolumn{3}{|l|}{ Main contractors } & \multicolumn{3}{|l|}{ Subcontractors } \\
\hline Criterion & RII & Rank & Criterion & RII & Rank \\
\hline Acquisition price and related terms and conditions & 0.850 & 5 & Acquisition price and related terms and conditions & 0.751 & 5 \\
\hline Price guarantees & 0.900 & 3 & Price guarantees & 0.773 & 4 \\
\hline Quality of materials used & 0.854 & 4 & Quality of materials used & 0.888 & 1 \\
\hline Supplier's financial health & 0.736 & 6 & Supplier's financial health & 0.724 & 7 \\
\hline Logistics & 0.689 & 7 & Logistics & 0.729 & 6 \\
\hline Communication, long-term cooperation & 0.932 & 1 & Communication, long-term cooperation & 0.822 & 3 \\
\hline Delivery date & 0.914 & 2 & Delivery date & 0.875 & 2 \\
\hline
\end{tabular}




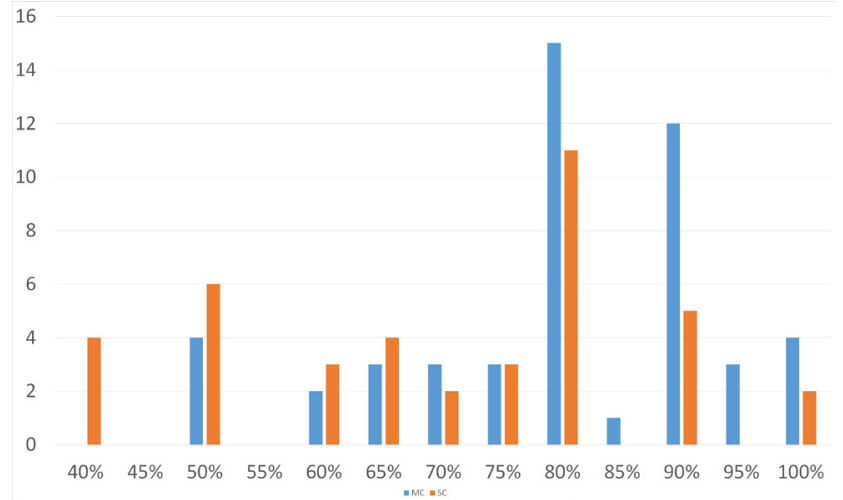

Fig. 2 Weight of price criterion

Fig. 2 shows the distribution of price criteria weighting for both main contractors and subcontractors and Table 5 shows descriptive statistics.

The data presented in Fig. 2 and Table 5 indicate that the weight of the price criterion is higher for main contractors, which is documented by both mean and median values. This finding is also supported by the data shown in Table 4 on the RII value of Acquisition price and related terms and conditions. This tendency could be attributed to the emphasis that subcontractors put on quality instead of price when compared with main contractors.

\subsection{Performance measurement}

The survey also enquired as to the usage of performance measurement of suppliers by respondents (see Table 6).

From the data in Table 6 it can be concluded that the role of the company in the supply chain does not influence the level of usage of performance measurement systems by suppliers. As the resulting values of relative frequencies give very similar results, the application of chi-square test is not needed in this case.

The users that apply performance measurement $(n=49)$ were then asked which measurement system they applied in practice (Table 7).

The $\chi^{2}$ test of independence takes the value of 1.483 under a 2 degrees of freedom resulting in the p-value of 0.476 .

\begin{tabular}{lccccc}
\multicolumn{5}{l}{ Table 5 Descriptive statistics for weight of price criterion [\%] } \\
\hline Category & Mean & Median & StDev & Min & Max \\
\hline MC & 80.00 & 80.00 & 13.51 & 50.00 & 100.00 \\
SC & 69.88 & 75.00 & 17.08 & 40.00 & 100.00 \\
\hline
\end{tabular}

\begin{tabular}{|c|c|c|}
\hline Category & Yes & No \\
\hline $\mathrm{MC}$ & $27(48.2 \%)$ & $29(51.8 \%)$ \\
\hline $\mathrm{SC}$ & $22(48.9 \%)$ & $23(51.1 \%)$ \\
\hline
\end{tabular}

Table 7 Type of performance measurement system used

\begin{tabular}{llll}
\hline Category & Simple ranking & Weighted ranking & Scoring \\
\hline MC & $14(51.9 \%)$ & $7(25.9 \%)$ & $6(22.2 \%)$ \\
SC & $8(36.4 \%)$ & $9(40.9 \%)$ & $5(22.7 \%)$ \\
\hline
\end{tabular}

Accordingly, there is not enough evidence to reject the null hypotheses of the independence of examined variables: the role of the company in the supply chain and type of performance measurement system used. Hypothesis H2 is not supported.

Table 8 shows the significance of performance criteria in terms of RII according to the role of the company in the supply chain. Data indicates that for both main contractors and subcontractors, meeting delivery deadlines counts as one of the most crucial criteria. This result can be explained by the use of contractual penalties for non-compliance with agreed deadlines, as delays are quite common in construction projects and can be due to various causes (Leśniak et al., 2018). Meeting the planned price is more important for main contractors than for subcontractors (RII $=0.948 ; 0.864$ respectively). This can be attributed to the need of main contractors to maintain sub-contractor budgets within set values, as rising sub-supply prices would negatively affect their profit margins.

The final question in this study addresses the frequency of performance measurement (see Table 9). Valid responses were received from 48 respondents. For both categories, annual assessment is the most common interval.

Table 8 Significance of performance measurement criteria (RII)

\begin{tabular}{|c|c|c|c|c|c|}
\hline \multicolumn{3}{|l|}{ Main contractors } & \multicolumn{3}{|l|}{ Subcontractors } \\
\hline Criterion & RII & Rank & Criterion & RII & Rank \\
\hline Quality of communication & 0.736 & 6 & Quality of communication & 0.781 & 6 \\
\hline Meeting delivery deadlines & 0.933 & 2 & Meeting delivery deadlines & 0.945 & 1 \\
\hline Number of claims of defects & 0.776 & 5 & Number of claims of defects & 0.782 & 5 \\
\hline Speed in remedying claims of defects & 0.840 & 3 & Speed in remedying claims of defects & 0.790 & 4 \\
\hline Ability to flexibly respond to changes in the project & 0.829 & 4 & Ability to flexibly respond to changes in the project & 0.863 & 3 \\
\hline Meeting the planned price & 0.948 & 1 & Meeting the planned price & 0.864 & 2 \\
\hline
\end{tabular}


Table 9 Frequency of performance measurement

\begin{tabular}{lcccc}
\hline Category & Annually & $\begin{array}{c}\text { Semi- } \\
\text { annually }\end{array}$ & $\begin{array}{c}\text { Quarterly and } \\
\text { shorter }\end{array}$ & $\begin{array}{c}\text { After each } \\
\text { contract }\end{array}$ \\
\hline MC & $15(55.6 \%)$ & $2(7.4 \%)$ & $6(22.2 \%)$ & $4(14.8 \%)$ \\
SC & $9(42.9 \%)$ & $1(4.8 \%)$ & $13(52.4 \%)$ & $0(0.00 \%)$ \\
\hline
\end{tabular}

However, subcontractors mostly prefer to assess performance of their suppliers with a frequency of up to 3 months (52.4\%). Another interesting finding is that some main contractors (14.8\%) perform performance assessment upon termination of each contract. This may be true in the case of large projects where the buyer-supplier relationship lasts for quite a long time (often more than six months).

\section{Conclusion}

This paper addressed the topic of supplier selection and performance measurement in the Czech construction industry. Based on the analysis of data collected through a web-based questionnaire survey, it was possible to investigate several interesting aspects such as the effect of the company role within the supply chain in various relations, significance of selection criteria, the degree of performance measurement usage and its frequency.

\section{References}

Araújo, M. C. B., Alencar, L. H., Mota, C. M. M. (2016) "Contractor selection in construction industry: A multicriteria model", In: 2015 IEEE International Conference on Industrial Engineering and Engineering Management (IEEM), Singapore, Singapore, pp. 519-523. https://doi.org/10.1109/IEEM.2015.7385701

Ceric, A. (2015) "Trust in Construction Projects: Literature Analysis Using Keywords", Organization, Technology and Management in Construction: An International Journal, 7(1), pp. 1179-1185. https://oi.org/doi:10.5592/otmcj.2015.1.2

Commission Recommendation 2003/361/EC of 6 May 2003 concerning the definition of micro, small and medium-sized enterprises (notified under document number C(2003) 1422) (Text with EEA relevance). [online] Available at: https://eur-lex.europa.eu/legal-content/ en/ALL/?uri=celex\%3A32003H0361 [Accessed: 15 August 2018]

Czech Statistical Office, official web site, [online] Available at: https:// www.czso.cz [Accessed 17 September 2018]

Čujan, Z., Málek, Z. (2008) "Výrobní a obchodní logistika" (Production and business logistics), Univerzita Tomáše Bati ve Zlíně, Zlín, Czech Republic. (in Czech)

de Araújo, M. C. B., Alencar, L. H., Mota, C. M. M. (2017) "Model for contractor performance evaluation in construction industry", In: 2016 IEEE International Conference on Systems, Man, and Cybernetics (SMC), Budapest, Hungary, pp. 002631-002635. https://doi.org/doi:10.1109/SMC.2016.7844636

Dormohammadi, A., Mohammadfam, I., Zarei, E. (2017) "Presentation of a practical framework for performance assessment of HSE
From a theoretical perspective, this research contributes to the current body of knowledge by providing original data on the situation in the study area consisting of the Czech Republic.

This research also has several implications for managerial practice. The practical findings presented in this paper may help purchasing professionals to develop their selection and performance measurement systems.

The sample size $(\mathrm{n}=101)$ did not permit other possible relations among the examined variables to be analysed, e.g. in relation to the size of the company. Therefore, future research should aim to extend the sample. Secondly, this analysis did not consider the aspect of the financial value of the delivery. Thirdly, this research presented findings based exclusively on quantitative data. Follow-up qualitative research could potentially provide additional valuable insights that would contribute to a better understanding of the attitudes of companies in this field.

\section{Acknowledgement}

This paper was written with the support of research grant FAST-S-18-5154 - Company costs and tender prices management in the construction sector.

in construction contractors", Iran Occupational Health, 13(6), pp. 10-22. [online] Available at: http://ioh.iums.ac.ir/browse.php?a code=A-10-1588-1\&slc_lang=en\&sid=1 [Accessed: 17 August 2018]

Elyamany, A., Abdelrahman, M., Cheng, F. C., Doetkott, C. (2013) "Developing a Quality Measure for Evaluating the Contractor Performance in Asphalt Pavement Construction", International Journal of Pavement Research and Technology, 6(1), pp. 22-30. https://doi.org/10.6135/ijprt.org.tw/2013.6(1).22

Hanák, T., Šelih, J. (2017) "On-line reverse auctions in construction industry", Građjevinar, 69(9), pp. 821-830. https://doi.org/10.14256/JCE.1352.2015

Hasnain, M., Thaheem, M. J., Ullah, F. (2018) "Best Value Contractor Selection in Road Construction Projects: ANP-Based Decision Support System", International Journal of Civil Engineering, 16(6), pp. 695-714. https://doi.org/10.1007/s40999-017-0199-2

Jaskowski, P., Biruk, S., Bucon, R. (2010) "Assessing contractor selection criteria weights with fuzzy AHP method application in group decision environment", Automation in Construction, 19(2), pp. 120-126. https://doi.org/10.1016/j.autcon.2009.12.014

Kovačić, N., Vukomanović, M., Radujković, M. (2014) "Implementation of Design and Build model in Croatian Construction Industry", In: International Scientific Conference People, Buildings and Environment 2014 (PBE2014), Kroměřǐž, Czech Republic, pp. 232-242. [online] Available at: https://www.fce.vutbr.cz/ekr/ pbe/Proceedings/2014/022_14181.pdf [Accessed: 07 August 2018] 
Kozik, R., Korytárová, J., Hanák, T., Radziszewska-Zielina, E. (2015) "Exploration of Contractor Evaluation Process in the Management of Public Works Contracts", In: Project Management as a Spectrum of Scientific Problems in Engineering and Management, WSOWL, Wroclaw, Poland, pp. 55-66.

Kraljic, P. (1983) "Purchasing must become supply management", Harvard Business Review, 1983, pp. 109-117.

Krzemiński, M. (2015) "The selection of construction sub-contractors using the fuzzy sets theory", AIP Conference Proceedings, 1648(1), Article number: 600005. https://doi.org/10.1063/1.4912837

Larsen, J. K., Shen, G. Q., Lindhard, S. M., Brunoe, T. D. (2016) "Factors Affecting Schedule Delay, Cost Overrun, and Quality Level in Public Construction Projects", Journal of Management in Engineering, 32(1), Article number: 04015032. https://doi.org/10.1061/(ASCE)ME.1943-5479.0000391

Leśniak, A., Piskorz, G., Spišáková, M., Mačková, D. (2018) "Causes of delays in construction works resulting from the provisions of the contract in Poland and Slovakia", Scientific Review Engineering and Environmental Sciences, 27(1), pp. 71-81.

https://doi.org/10.22630/PNIKS.2018.27.1.7

Markovits-Somogyi, R., Gecse, G., Bokor, Z. (2011) "Basic efficiency measurement of Hungarian logistics centres using data envelopment analysis", Periodica Polytechnica Social and Management Sciences, 19(2), pp. 97-101. https://doi.org/10.3311/pp.so.2011-2.06

Pesämaa, O., Larsson, J., Erik Eriksson, P. (2018) "Role of Performance Feedback on Process Performance in Construction Projects: Client and Contractor Perspectives", Journal of Management in Engineering, 34(4), Article number: 04018023. https://doi.org/10.1061/(ASCE)ME.1943-5479.0000619

Qian Li, Z., Chen Tan, H., Anumba, C., Choy Chia, F. (2017) "Development of a web-based system for managing suppliers' performance and knowledge sharing in construction project", Built Environment Project and Asset Management, 7(2), pp. 117-129. https://doi.org/doi:10.1108/BEPAM-10-2015-0061

Rajgor, M., Paresh, C., Dhruv, P., Chirag, P., Dhrmesh, B. (2016) "RII \& IMPI: Effective Techniques for Finding Delay in Construction Project", International Research Journal of Engineering and Technology (IRJET), 3(1), pp. 1173-1177. [online] Available at: https://www.irjet.net/archives/V3/i1/IRJET-V3I1203. pdf [Accessed: 20 September 2018]

Safa, M., Shahi, A., Haas, C. T., Hipel, K. W. (2014) "Supplier selection process in an integrated construction materials management model", Automation in Construction, 48, pp. 64-73. https://doi.org/doi:10.1016/j.autcon.2014.08.008

Samson, A., Voyer, B. G. (2014) "Emergency purchasing situations: Implications for consumer decision-making", Journal of Economic Psychology, 44, pp. 21-33. https://doi.org/doi:10.1016/j.joep.2014.05.004

Singh, D., Tiong, R. L. K. (2006) "Contractor Selection Criteria: Investigation of Opinions of Singapore Construction Practitioners", Journal of Construction Engineering and Management, 132(9), pp. 998-1008.

https://doi.org/10.1061/(ASCE)0733-9364(2006)132:9(998)
Taylan, O., Kabli, M. R., Porcel, C., Herrera-Viedma, E. (2018) "Contractor Selection for Construction Projects Using Consensus Tools and Big Data", International journal of Fuzzy Systems, 20(4) pp. 1267-1281. https://doi.org/10.1007/s40815-017-0312-3

Topcu, Y. I. (2004) "A decision model proposal for construction contractor selection in Turkey", Building and Environment, 39(4), pp. $469-481$.

https://doi.org/10.1016/j.buildenv.2003.09.009

Ulubeyli, S., Manisali, E., Kazaz, A. (2010) "Subcontractor Selection Practices in International Construction Projects", Journal of Civil Engineering and Management, 16(1), pp. 47-56. https://doi.org/10.3846/jcem.2010.04

Yousef AlMaian, R., LaScola Needy, K., Walsh, K. D., Da Alves, T. C. L. (2015) "Supplier Quality Management Inside and Outside the Construction Industry", EMJ - Engineering Management Journal, 27(1), pp. 11-22. https://doi.org/10.1080/10429247.2015.11432032

Vörösmarty, G., Dobos, I. (2019) "Supplier Evaluation with Environmental Aspects and Common DEA Weights", Periodica Polytechnica Social and Management Sciences, 27(1), pp. 17-25. https://doi.org/10.3311/PPso.11814

Vukomanovic, M., Radujkovic, M. (2013) "The Balanced Scorecard and EFQM Working Together in a Performance Management Framework in Construction Industry", Journal of Civil Engineering and Management, 19(5), pp. 683-695. https://doi.org/10.3846/13923730.2013.799090

Zavadskas, E. K., Turskis, Z., Tamošaitiene, J. (2008) "Contractor Selection of Construction in a Competitive Environment", Journal of Business Economics and Management, 9(3), pp. 181-187. https://doi.org/10.3846/1611-1699.2008.9.181-187 